\title{
Ю.І. Карпенко, Сабер Гармазі ДИНАМІКА ВЕГЕТОЛОГІЧНИХ ПОКАЗНИКІВ У ХВОРИХ НА РЕФРАКТЕРНУ АРТЕРІАЛЬНУ ГІПЕРТЕНЗІЮ ЗАЛЕЖНО ВІД ВИДУ ВИКОРИСТАНОГО ЛІКУВАННЯ
}

Одеський національний медичний університет

Резюме. Метою дослідження $є$ оцінка клінічної ефективності катетерної радіочастотної селективної денервації ниркової артерії з використанням навігаційної системи тривимірної реконструкції аорти і ниркових артерій. Доведено, що після виконаного оперативного втручання відбувається нормалізація артеріального тиску та зменшується вираженість активації симпато-адреналової системи. Обговорюється доцільність

Вступ. Резистентна до фармакотерапії артеріальна гіпертензія (РАГ) в останні роки викликає інтерес у фахівців у всьому світі. Це пов'язано зі значною поширеністю цієї патології. За даними експертів Європейського товариства кардіологів, РАГ відзначається у 15-30 \% випадків артеріальної гіпертензії [1, 2]. Roberie D.R. et al. (2012) стверджують, що протягом останніх 25 років частота РАГ у США зросла з 8,8 \% до 20,7 \% [3].

Відповідно до сучасних уявлень під РАГ розуміють випадки артеріальної гіпертензії, резистентної до лікування не менше, ніж трьома антигіпертензивними лікарськими засобами, включаючи діуретик, тобто, без досягнення цільових значень артеріального тиску (АТ). РАГ є гетерогенною групою патологічних станів, для яких основними патогенетичними механізмами $\epsilon$ активація симпатоадреналової системи (САС), ренін-ангіотензинальдостеронової системи (РААС). До числа патологічних станів, асоційованих із РАГ, належать гіперальдостеронізм, обструктивне нічне апное, хронічна хвороба нирки, феохромоцитома тощо [1, 4]. Одним із найбільш важливих елементів патогенезу РАГ є підвищена активність симпатичних нервів ниркових артерій. Постгангліонарні адренергічні волокна ниркового нерва виступають джерелом аферентної імпульсації, яка забезпечує активацію CAC та РАAC із формуванням передумов для гіперальдостеронізму [1].

Враховуючи особливості симпатичної іннервації нирки, а саме те, що аферентні і еферентні симпатичні нервові волокна, що іннервують нирку, проходять безпосередньо в стінці головної ниркової артерії (НА), тісно обплітаючи іï периметр. Значно більш перспективним є застосування катетерної радіочастотної симпатичної денервації ниркової артерії (КРСДНА), яка дозволяє провести селективну денервацію симпатичних гангліїв без порушення функції нирок і іннервації органів черевної порожнини і нижніх кінцівок. Безпека методу симпатичної денервації нирок і його антигіпертензивна ефективність вивчена в декількох клінічних дослідженнях $[5,6]$. Менш поширеними є альтернативні методи лікування, в тому числі стимуляція барорецепто- застосування хірургічного методу лікування резистентної артеріальної гіпертензії з використанням селективної симпатичної денервації ниркових артерій, яка $€$ патогенетично обгрунтованою.

Ключові слова: артеріальна гіпертензія, лікування, клінічна ефективність.

рів каротидного гломуса, фокусований вплив ультразвуком, термотерапія та застосування інших преформованих фізичних факторів [7-9].

Мета дослідження. Оцінити клінічну ефективність КРСДНА з використанням навігаційних систем тривимірної реконструкції аорти і НА.

Матеріал і методи. Дослідження виконано на базі Обласної клінічної лікарні (м. Одеса). Обстежено 50 хворих з РАГ (основна група) з визначенням загального вегетативного тонусу, середній вік яких склав $(59,5 \pm 0,4)$ років і 30 хворих 3 РАГ, яким використовували трьох і більше компонентну антигіпертензивну терапію (контрольна група), середній вік яких склав $(56,9 \pm 0,7)$ років.

Для визначення загального вегетативного тонусу використовували таблицю «24 стигми» [10]. 3 метою оцінки вегетативної реактивності (ВР) вивчали окосерцевий рефлекс Ашнера-Даньїні. Дослідження вегетативного забезпечення діяльності проводилося за допомогою експериментального моделювання розумової діяльності [10].

Холтерівське моніторування ЕКГ проводили за допомогою портативного пристрою «Cardiotens» (Угорщина) [11].

У $23(46,0 \%)$ хворих на РАГ виконана КРСДНА. У структурі вибірки переважали жінки (22 або 44,0 \%), 3 них КРСДНА виконана 10 (43,5 \% від числа прооперованих). Середній вік пацієнтів склав $56,5 \pm 0,6$ року. У 9 (39,1 \%) випадках процедура КРСДНА проводилася в поєднанні з ізоляцією легеневих вен.

Тривимірна реконструкція аорти і ниркових артерій із застосуванням системи тривимірного анатомічного картування (ТАК) EnSite NavX, St Jude Medical (США) з подальшою прецизійною КРСДНА виконана у 14 (60,9 \%) пацієнтів (основна група). У 9 (39,1 \%) процедурах КРСДНА проводилася під флюороскопічним контролем (контрольна група).

Критерії включення: рефрактерна до комплексної антигіпертензивної терапії АГ (АТ> 160/90 мм рт.ст. на тлі трьох антигіпертензивних препаратів, включаючи діуретики); швидкість клубочкової фільтрації> 45 мл / хв / м2. Критерії 
виключення для виконання процедури: верифікована симптоматична АГ; цукровий діабет I типу; верифікований значущий стеноз ниркової артерії; стентування ниркової артерії в анамнезі.

У дослідженні використана модифікована методика КРСДНА застосуванням системи тривимірного анатомічного картування (ТАК) EnSite NavX, St Jude Medical (СШÀ) [12].

Статистичний аналіз отриманих даних проведено за допомогою програмного забезпечення STATISTICA 12.6 (StatSoft Inc., СШA) [2].

Результати дослідження та їх обговорення. При оцінці клінічного статуса встановлено, що АТ у пацієнтів основної групи на тлі застосування декількох препаратів становив до лікування в середньому 174,5 $\pm 9,3$ мм рт. ст. (систолічний АТ) на $111,7 \pm 5,8$ мм рт. ст. (діастолічний АТ).

Процедура розглядалася як ефективна при зниженні середнього рівня АТ систолічного більш ніж на 30 мм рт. ст. і АТ діастолічного більш ніж на 10 мм рт. ст. Період спостереження становив від 4

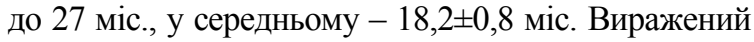

гіпотензивний ефект після КРСДНА був у 19 (82,6 \%) прооперованих. Тривалість процедури склала $76,7 \pm 2,4$ хв у пацієнтів, прооперованих із ТАК і $56,2 \pm 3,3$ хв із рентгенологічним контролем. Як свідчать дані рисунка, достовірне зниження як систолічного, так і діастолічного тиску відзначалося вже через один місяць після процедури. Зазначені зміни зберігалися і у віддаленому періоді.

Як видно з представлених даних, при порівнянні ефективності в клінічних групах відзначалося достовірне, більш виражене зниження АТ в основній групі. Цей факт підтверджений холтерівським моніторуванням, яке дозволило виявити ознаки активації симпатичної нервової системи.

Як видно з таблиці, у пацієнтів із неконтрольованою гіпертензією вихідні показники ЧСС і SDNN були достовірно вищими $(\mathrm{p}<0,05)$ порівняно $з$ контрольною групою. При порівнянні показників ВСР у пацієнтів 3 ХCH різного віку нами встановлено наявність достовірних відмінностей за рядом параметрів, вибраних для аналізу, що свідчить про зміни у вегетативній регуляції серцевого

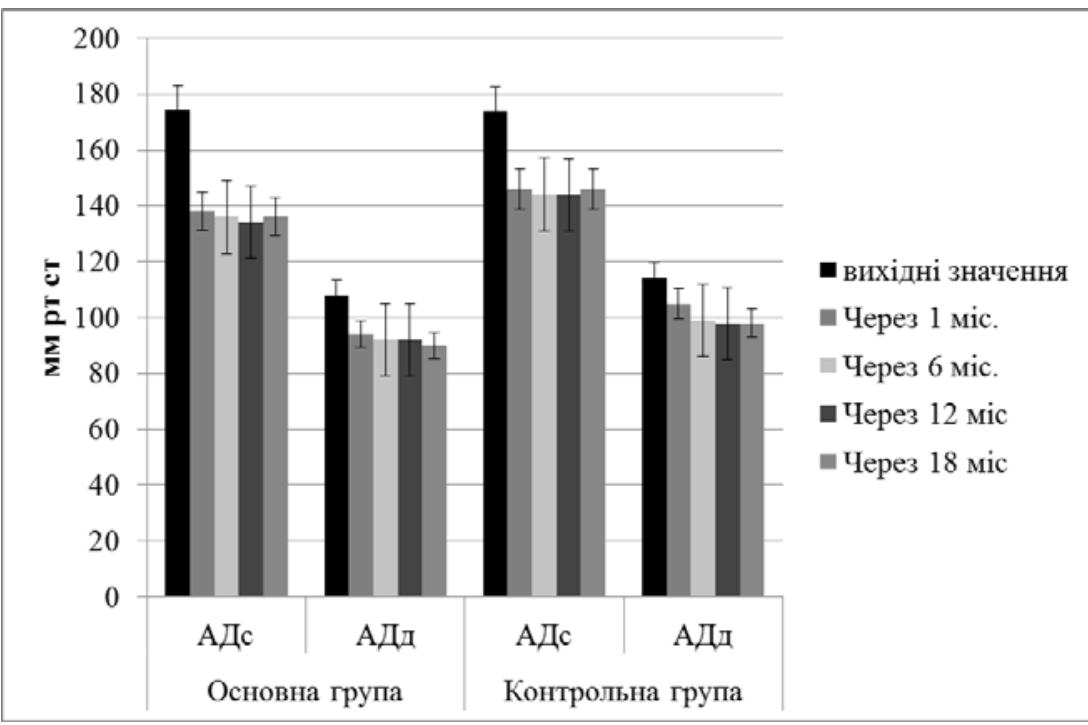

Рис. Динаміка артеріального тиску після катетерної радіочастотної симпатичної денервації ниркової артерії

Таблиця

Показники варіабельності серцевого ритму в обстежених осіб

\begin{tabular}{|c|c|c|c|}
\hline \multirow{2}{*}{ Показник } & \multirow{2}{*}{$\begin{array}{c}\text { Контрольна група } \\
(\mathrm{n}=30)\end{array}$} & До лікування & Після лікування \\
\cline { 3 - 4 } & $764,3 \pm 6,5$ & $691,2 \pm 4,4^{*} \#$ & $755,5 \pm 4,6$ \\
\hline NN (мс) & $45,9 \pm 0,8$ & $34,3 \pm 0,6^{*} \#$ & $43,8 \pm 1,2$ \\
\hline SD NNi (мс) & $127,6 \pm 2,0$ & $67,9 \pm 1,1^{*} \#$ & $124,4 \pm 1,8$ \\
\hline SDANN (мс) & $29,6 \pm 0,5$ & $27,4 \pm 0,2 \#$ & $29,1 \pm 0,3$ \\
\hline RMSDD (мс) & $10,5 \pm 0,2$ & $7,7 \pm 0,1^{*} \#$ & $9,8 \pm 0,2$ \\
\hline PNN50, \% & $10,6 \pm 0,1$ & $11,0 \pm 0,1^{* \#}$ & $10,8 \pm 0,1$ \\
\hline TI, од & $2188,8 \pm 90,4$ & $1355,5 \pm 34,7 * \#$ & $1985,2 \pm 43,2$ \\
\hline TP & $300,2 \pm 5,8$ & $292,3 \pm 12,8 \#$ & $295,4 \pm 9,9$ \\
\hline HF & $644,5 \pm 26,8$ & $245,6 \pm 15,3^{* \#}$ & $590,3 \pm 19,7$ \\
\hline LF & $2,1 \pm 0,1$ & $0,8 \pm 0,1 * \#$ & $2,0 \pm 0,1$ \\
\hline LF/HF & &
\end{tabular}

Примітка. * - відмінності з контролем є статистично значущими (p<0,05); \# - відмінності значень до та після лікування є статистично значущими $(\mathrm{p}<0,05)$ 
ритму. Це стосується насамперед співвідношення LF / HF, яке у хворих основної групи різко зрушувалося вліво (до 0,8/0,1), за рахунок збільшення активності HF (high frequency) компонента і зниження активності LF (low frequency) компонента.

\section{Висновок}

1. Таким чином, після виконаного оперативного втручання відбувається нормалізація вегетативного тонусу в пацієнтів із резистентною артеріальною гіпертрнзією. При цьому, дані інструментального дослідження відповідали результатам клінічного обстеження. Так, якщо до оперативного втручання у 39 (78,0 \%) пацієнтів основної групи мала місце симпатикотонія, то після проведеного лікування кількість осіб з вираженою симпатикотонією зменшилася до 2 (4,0 \%). Крім того, у пацієнтів основної групи після катетерної радіочастотної симпатичної денервації ниркової артерії нормалізувалася вегетативна реакція та зникли прояви надмірної активності ерготропних апаратів надсегментарних структур вегетативної нервової системи.

2. Отже, застосування хірургічного методу лікування резистентної артеріальної гіпертензї, у вигляді селективної симпатичної денервації ниркових артерій, є патогенетично обгрунтованим та достатньо ефективним.

\section{Література}

1. Сафроненко А.В Неврологические и психологические особенности больных с рефрактерной артериальной гипертензией / А.В. Сафроненко, Ю.С. Макляков // Урал. мед. ж. - 2012. - № 1. - С. 36-39.

2. Трухачева Н.В. Математическая статистика в медикобиологических исследованиях с применением пакета STATISTICA / H.B. Трухачева. - М., 2012. - 379 с.
3. Effects of renal denervation on sympathetic activation, blood pressure, and glucose metabolism in patients with resistant hypertension / M. Schlaich, D. Hering P. Sobotka [et al.] // Frontiers Physio. - 2012. - Vol. 1. - P. 3-10.

4. EnSite $^{\mathrm{TM}} \mathrm{Nav} \mathrm{X}^{\mathrm{TM}}$ Navigation \& Visualization Technology. Электронный peсурс. Режим доступа: http:// professional.sjm.com/products/ep/mapping-visualization/ disposable-products/ensite-navx-navigation-visualizationtechnology

5. Kotchen T. Historical trends and milestones in hypertension research: a model of the process of translational research $/ \mathrm{T}$. Kotchen // Hypertension. - 2010. - Vol. 58. - P. 522-538.

6. Laffin L.J. Renal denervation for resistant hypertension and beyond / L.J. Laffin, G.L. Bakris // Adv Chronic Kidney Dis. -2015 . - Vol. 22 (2). - P. 133-139.

7. Mafeld S. Renal Denervation for Treatment-Resistant Hypertension / S. Mafeld // Ther. Adv. Cardiovasc. Dis. 2012. - Vol. 6. - P. 245-258.

8. Refractory hypertension: definition, prevalence, and patient characteristics / M.C. Acelajado, R. Pisoni, T. Dudenbostel [et al.] // J. Cli. Hypertens (Greenwich). - 2012. Vol. 14 (1). - P. 7-12.

9. Renal sympathetic denervation in patients with treatmentresistant hypertension. The Symplicity HTN-2 trial: a randomised controlled trial / M. Esler, H. Krum, M. Schlaich [et al.] // Lancet. - 2010. - Vol. 376. - P. 1903-1909.

10. The World Health Organization recognizes noncommunicable diseases and raised blood pressure as global health priority for 2025 / D.L. Cohen, R.R. Townsend, S.Y. Angell [et al.] // J. Clin. Hypertens (Greenwich). - 2014. Vol. 16 (9). - P. 624.

11. Uder M. Renal artery denervation for the treatment of hypertension: opening up new horizons / M. Uder, A. Schmid, S. Titze // Cardiovasc. Intervent. Radiol. 2011. - Vol. 34. - P. 442-444.

12. Vascular lesions induced by renal nerve ablation as assessed by optical coherence tomography: pre- and postprocedural comparison with the Simplicity catheter syste$\mathrm{m}$ and the EnligHTN multi-electrode renal denervation catheter / C. Templin, M. Jaguszewski, J.R. Ghadri [et al.] // Eur. Heart J. - 2013. - Vol. 34 (28). - P. 2141-2148.

\section{ДИНАМИКА ВЕГЕТОЛОГИЧЕСКИХ ПОКАЗАТЕЛЕЙ У БОЛЬНЫХ РЕФРАКТЕРНОЙ АРТЕРИАЛЬНОЙ ГИПЕРТЕНЗИЕЙ В ЗАВИСИМОСТИ ОТ ВИДА ИСПОЛЬЗОВАННОГО ЛЕЧЕНИЯ}

\section{Ю.И. Карпенко, Сабер Гармази}

Резюме. Целью исследования является оценка клинической эффективности катетерной радиочастотной селективной денервации почечной артерии с использованием навигационных систем трехмерной реконструкции аорты и почечных артерий. Доказано, что после выполненного оперативного вмешательства происходит нормализация артериального давления и уменьшается выраженность активации симпатоадреналовой системы. Обсуждается целесообразность применения хирургического метода лечения резистентной артериальной гипертензии с использованием селективной симпатической денервации почечных артерий, которая является патогенетически обоснованной.

Ключевые слова: артериальная гипертензия, лечение, клиническая эффективность.

\section{DYNAMICS OF VEGETOLOGICAL PARAMETERS IN PATIENTS WITH REFRACTORY HYPERTENSION DEPENDING ON THE TYPE OF TREATMENT USED}

\section{Y.I. Karpenko, Saber Harmazi}

Abstract. The aim of the study is to evaluate the clinical efficacy of radiofrequency catheter selective denervation of the renal artery using the navigation systems with three-dimensional reconstruction of the aorta and renal arteries. It was proved that the surgery performed after a normalization of blood pressure and decreases the severity activation sympathoadrenal system. We discuss the feasibility of surgical treatment of resistant hypertension, as selective sympathetic denervation of the renal arteries is pathogenetically grounded.

Key words: hypertension, treatment, clinical efficacy.

State Medical University (Odessa)

Рецензент - проф. І.А. Плеш

(C) Ю.І. Карпенко, Сабер Гармазі, 2015
Buk. Med. Herald. - 2015. - Vol. 19, № 4 (76). - P. 78-80 